\title{
Influence of tides and winds on fishing techniques and strategies in the Mamanguape River Estuary, Paraíba State, NE Brazil
}

\author{
DANDARA M.M. BEZERRA ${ }^{1}$, DOUGLAS M. NASCIMENTO ${ }^{2}$, EMMANOELA N. FERREIRA ${ }^{1}$, \\ POLLYANA D. ROCHA ${ }^{3}$ and JOSÉ S. MOURÃO ${ }^{4}$ \\ ${ }^{1}$ Programa de Pós-Graduação em Ciências Biológicas, Zoologia, Departamento de Sistemática e Ecologia, \\ Centro de Ciências Exatas e da Natureza, Universidade Federal da Paraíba, Campus I, \\ Bairro Castelo Branco, Cidade Universitária, 58051-900 João Pessoa, PB, Brasil \\ ${ }^{2}$ Programa de Pós-Graduação em Etnobiologia e Conservação da Natureza (PPGEtno), \\ Departamento de Biologia, Universidade Federal Rural de Pernambuco (UFRPE), \\ Rua Dom Manoel de Medeiros, s/n, Dois Irmãos, 52171-900 Recife, PE, Brasil \\ ${ }^{3}$ Departamento de Biologia, Universidade Estadual da Paraíba, Av. Baraúnas, 351, \\ Campos Universitário Bodocongó, 58109-753 Campina Grande, PB, Brasil \\ ${ }^{4}$ Departamento de Biologia, Universidade Estadual da Paraíba, \\ Av. Baraúnas, 351, Campos Universitário Bodocongó, 58109-753 Campina Grande, PB, Brasil
}

Manuscript received on May 3, 2010; accepted for publication on April 28, 2011

\begin{abstract}
This work was carried out in two small fishing communities, Barra de Mamanguape and Tramataia, Northeastern Brazil. The aim was to study these traditional fishermen's knowledge and perception about tide and wind classifications, as well as their fishing strategies and techniques. Our research methodology involved various techniques: free interviews and semi-structured ones, guided tours and direct observations. The results obtained show the fishermen's classification of the tides according to the phases of the moon: 'breaking tide', 'flushing tide', 'dead tide' and 'big tide' designated technically these last as neap tide and spring tide, respectively. Wind is also an essential factor for the fishermen to make successful catches, and they classify it according to direction: North, South, East, Southeast, Southwest, Northeast and Northwest. The data show that fishermen's knowledge can also be useful in devising plans for management and conservation studies for this estuary.
\end{abstract}

Key words: Artisanal fishing, ethnoictihology, fish, fishing communities, lunar-tide cycle.

\section{INTRODUCTION}

Within the context of the relation society-nature, in the universe of fishermen it is possible to encounter evidence of mechanisms of a natural and cultural order, which can guarantee the reproduction of their social, historical, economic and cultural

Correspondence to: Dandara Monalisa Mariz Bezerra

E-mail: dand.biologa08@gmail.com system (Cunha 2004). This author draws attention to the indicator systems, a combination of winds, tidal conditions and the moon phases, signalling favorable or non-favorable conditions for fishing, as truly natural mechanisms interposed in the fishing universe. The mechanisms are elaborated or socially acquired, based on observation, experimentation and cosmo-vision. 
Thus, the climatic factors that most directly intervene in fishing activity are the winds and the periodicity of the tides. According to Kuparinen et al. (2009), lunar cycles are commonly believed to affect fishery catches through changes in the behavior and movements of fishes, to affect feeding, vertical distribution and catchability of several marine and freshwater fishes. These meteorological elements constitute two fundamental occurrences in the functioning of fishing strategies, playing primary limiting roles, given that, depending on their intensity, they can impede fishing activity and modify fishing plans in short, medium and long terms (Allut 2000). This same author states that only meticulous knowledge on the dynamics of meteorological factors and the aspects related to fishing allows fishermen to have a degree of response to their environment, enabling them, to a certain extent, to make forecasts.

Time, atmosphere and tidal cycles have precise meanings in fishing activity (Cardoso 2001). However, since the beginning of time, the observation of the sky has always served as a knowledge base for all societies, submitted in conjunction with the cyclical movement of phenomena like day and night, the moon phases and the seasons. The indigenous, since long ago, have perceived that hunting, gathering, fishing and agricultural activities depend on to seasonal fluctuation, and they have sought to unveil the fascinating mechanisms that govern these cosmic processes in order to use them in favor of the survival of their communities (Afonso 2006).

The scientific community knows very little about the "astronomy" of traditional communities and its relation with their knowledge on meteorological processes. It constitutes treasure facing extinction just like biological resources. In this perspective, Cordell (1974) was one of the pioneers in the study of the classification that the fishermen from Arembepe - BA make for tidal movements associated to the various lunar phases. However, few studies show this theme, like Cordell (1974), Mourão (2000), Nishida (2000),
Sanches (2001), Alves and Nishida (2002), Godefroid et al. (2003), Ramires and Barrella (2003), Nishida et al. (2006a, b) and Ono and Addison (2009).

Ono and Addison (2009) studied rich traditions of fishing made by Tokelauan from New Zealand focusing on fishing practices, technologies and materials and related them to fish ecology, demonstrated the wisdom of this community and could serve as an example for many island communities where fishing is quickly changing under the pressures of modern life.

All this knowledge and perception of natural phenomena have allowed the traditional fishermen to build up their know-how and techniques to exploit the resources in their environment and adapt themselves to it. Consequently, traditional fishing shows a great diversity of technique and strategy according to the range of species to be caught (Netto et al. 2002). This variation in the use of devices is related to the kind of environment exploited and the target species (Maia and Rocha-Barreira 2008). Chaves and Robert (2003) studied a variety of fishing techniques used in many regions of the Brazilian coast, such as drag, cast, 'emalhe' nets (mesh net) and 'espinhel' (long line), among others. Silvano (2004) states that just on the Paraná coast, more than 15 different methods of fishing can be recognized, some of which are remarkable for their economic importance.

The fishing strategy can be defined by a combination of instruments, target species and geographical location, plus, the influence of abiotic factors (Montenegro et al.2001).According to Cordell (1974), the determination of where and how to fish every day is generally based on a set of pre-determined environmental information, and the origin of this information is the perception that fishermen know the cyclical regularity of tides, which affects both the mechanical operations of the fishing methods and the distribution of the species throughout the estuary. The lunar phase can exert an influence on the specific composition of a region's ichtyofauna, either because of the variation caused by the nightlight or because 
of its action on the variation in tide level (Quinn and Kojis 1981, Rooker and Dennis 1991, Godefroid et al. 2003). Besides these, the reproductive activities related to the lunar cycle, such as the aggregation for spawning, can cause significant effects on the temporal variation regarding fish abundance (Johannes 1978, Godefroid et al. 2003).

The traditional ecological knowledge represents multiple facets of know-how accumulated over many generations of intense interaction between people and the natural world (Drew 2005), enabling important contributions vis-à-vis with the recent awareness about loss of biological diversity, the need to know and comprehend the tropical ecosystems, as well as the cooperation with management programs (Berkes 1999, Drew 2005, Anwani and Vaccaro 2008). This research aimed to describe the way traditional fishermen from the communities of Barra de Mamanguape and Tramataia, located on the shores of the Mamanguape River Estuary, on the Paraíba State coast, NE Brazil, classify the tides and the winds, as well as the influence of these factors on their fishing strategies and techniques.

\section{MATERIALS AND METHODS}

The Mamanguape River Estuary - MRE (Fig. 1) is located on the septentrional part of the Paraíba coast, around $80 \mathrm{~km}$ from the city of João Pessoa. It covers an area of 5,721 ha of mangrove bounded by latitudes $6^{\circ} 43^{\prime} 02^{\prime \prime} \mathrm{S}$ to $6^{\circ} 51^{\prime} 54^{\prime \prime} \mathrm{S}$ and longitudes $35^{\circ} 07^{\prime} 46^{\prime}$ " W to $34^{\circ}$ 54' 04" W (Paludo and Klonowski 1999).

The fishing communities studied were Barra de Mamaguape and Tramataia, located in the Barra de Mamanguape Área de Proteção Ambiental - APA [Environmental Protection Area], on the shores of the MRE. These settlements are basically formed by a mixture of Indian, black and white racial

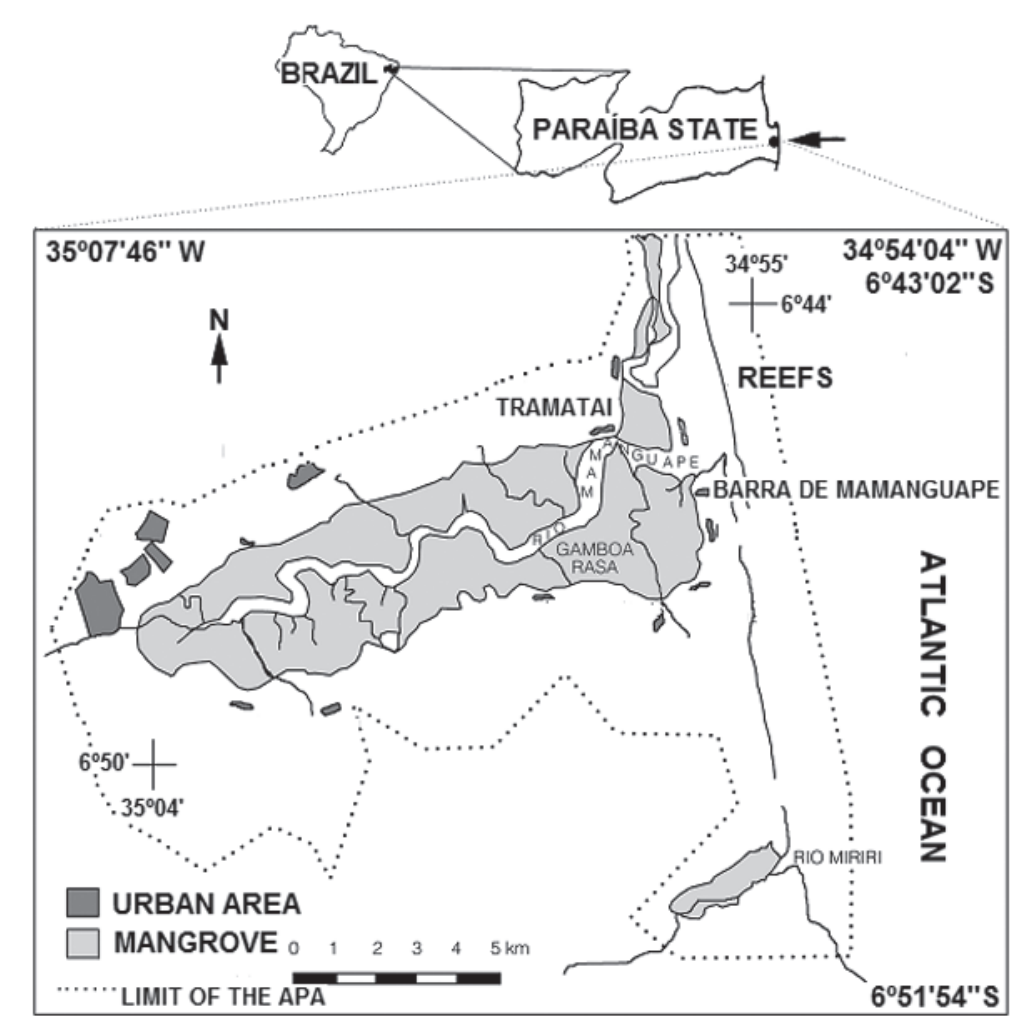

Fig. 1 - Map of the localization of the Mamanguape River Estuary - MRE. 
elements, and they conduct extractive activities in the area around the Mamanguape River (Paludo and Klonowski 1999, Mourão and Nordi 2003).

The field work was carried out in the period of November 2006 to March 2007, with two trips per month. 23 male fishermen were altogether interviewed, 15 from the Barra de Mamanguape community and 8 from the Tramataia community, with ages ranging from 25 to 67 . The research project was submitted to the Ethics Committee in Research of the State University of Paraíba and approved (protocol number: 0365.0.133.00-08). In addition, the fishermen were asked if they wanted to take part in the study. All of them were free to withdraw from the research at any time. Initially, mutual trust and rapport between researcher and interviewee were established through free non-organized interviews (Costa-Neto and Marques 2000). For the free interviews, the "snowball" technique (Bailey 1982) was used, in which each informer indicates others who know about the researched subject. Semistructured interviews followed this one, enabling the gathering of fishing data concerning the knowledge of techniques and strategies related to the tides, moon, winds and the seafood caught. The mesh of fishing nets was measured between adjacent knots using a metal ruler with $1 \mathrm{~mm}$ graduations in order to relate its size to its catch selectivity.

The interviews were recorded manually and with the aid of a cassette or MP3 recorder, and then transcribed. These recordings can be found at the Ethnoecology/Ethnobiology Nucleus of Paraíba State University. Besides the interviews, a direct observation technique was used (Stebbins 1987), in which the researcher is a non-participant observer. The aim was to provide a better understanding of the fishing techniques and strategies, to learn about the local denominations for the tide and the winds to and make the photographic registration.

For the analysis and control of data, some were performed tests to verify the consistency and validity of the replies in synchronic and diachronic situations; the first lot occurred when the same question was posed to different people in a very short space of time, and the second when a question was repeated to the same individual in a distinct period of time. The data were analyzed using qualitative emicist and ethicist approaches (Costa-Neto and Marques 2000), in which the traditional knowledge was compared to the corresponding and/or co-related knowledge found in the scientific literature. The behavior was evaluated according to the environmental implications that arose, and the thoughts deduced by looking for possibilities of cognitive/behavioral linking.

\section{RESULTS}

\section{TIDES ClassifiCATION}

By means of the interviews, it was possible to organize the way the traditional fishermen classify the effect of the moon on the periodicity of the tides. Figure 2 shows that the 'breaking tide' corresponds to the amplitude variation between the tides when they start to decrease; 'flushing tide' means the amplitude variation between the tides when they start to increase; 'dead tide' means the minimum amplitude variation between the tides that occurs in the days when the sun and the moon pull at right angles to the earth; the 'big tide' happens when there are the greatest amplitude variations between high and low tides. The tide called 'head of dead water' means the last days of the 'dead tide' as the moon starts to change to waning crescent phase.

The 'big tide' is responsible for as causing the highest and lowest amplitude of water level and has a strong flow: during the big tide, it influences the kind of water flow and the water into that enters mangrove, making the flow more intense in the estuary and spreading out over the 'croas' (sandyclayloam shores) (Eufrásio - fisherman). The 'dead tide' is thus nominated because the low and high tide oscillations are minimal and the flow is weaker: the dead tide lowers the water and decreases its flows less (Bio Aristóteles - fisherman). The 'breaking 


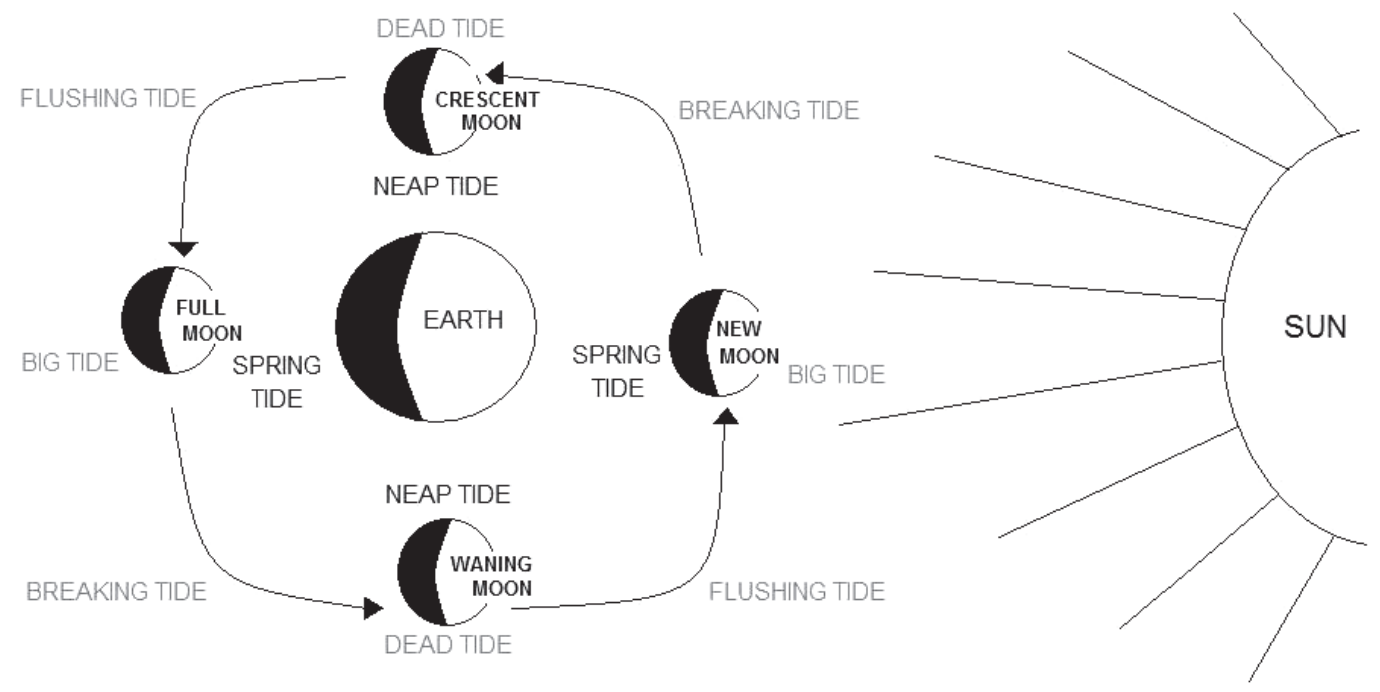

Fig. 2 - Classification, according to the knowledge, of the fishermen from MRE of tidal movements associated with the lunar cycle.

tide' is distinguished by the daily lowering of the tide level and the water flow until it reaches the same stage as the 'dead tide': it's getting less water (Caroba - fisherman). The 'flushing tide' means a gradual increase in the water level and flow until it reaches the 'big tide' level: water's coming and getting higher (Vermelho - fisherman).

Besides the tides mentioned, the MRE fishermen also named the tides according to the water level in relation to the sand banks (high tide, low tide, thick tide of flood, thick tide of ebb, low tide of flood, low tide of ebb), to the lunar phases (tide of moon, tide of quarter), and to the period of occurrences (dark tide, twilight tide) (Table I).

\section{ThE TIDAL INFLUENCES ON FISHING TECHNIQUES} AND STRATEGIES

The fishing nets made of nylon can be used for four different modalities: 'cerco', 'caceia', 'de espera' and 'de zangaria' fishing.

Siege fishing ('cerco') is aimed at mullets ( $M$. curema) and usually performed by three fishermen. They identify the shoals; with a rowing boat, cast a mullet net ('tainheira') and follow the shoal movement until the net almost surrounds it. Then a fisherman beats the water with a wooden rod to drive the shoal towards the net. The same type of net is also used to catch 'sauna', the youthful stage of a mullet; also it catches sardines (Clupeidae), catfish (Ariidae) and 'tamataranas' (M. curvidens, $M$. incilis, M. gaiamardianus). This strategy is used at low tides of big tides or syzygy, when the fishermen manage to visualize the shoals more easily.

The fishing of 'caceia' consists of a strategy in which the fishermen pay out the net, allowing the current to take it until a certain point where the fish get trapped in it. The nets used can be the mullet net, which captures M. curema, Centropomus undecimalis, Pomadasys ramosus and other species of the families Ariidae and Gerreidae; gillnet ('sauneiro'), which captures species of the families Ariidae e Mugilidae and gillnet ('caçoeira'), which catches species of the families Ariidae, Centropomidae, Gerreidae, Mugilidae and Sciaenidae. In these cases, the suitable tides are high tides of big tides and the flushing tide, because these tides provide the current needed in the transportation network by water.

Another strategy used by the fishermen is the 'zangareia', which is characterized by the vertical fixing of a mullet net, which starts laid 
TABLE I

Classification system of the tides according to fishermen (23 interviewees) from the MRE and its characteristics and correlation with the scientific classification of tides.

\begin{tabular}{|c|c|c|}
\hline $\begin{array}{l}\text { Classification according } \\
\text { to the fishermen }\end{array}$ & Characteristics & Scientific classification \\
\hline Big tide & Occurs with the full and new moon. & Spring tide \\
\hline Dead tide & $\begin{array}{l}\text { Occurs with waning moon and } \\
\text { crescent moon }\end{array}$ & Neap tide \\
\hline Breaking tide & $\begin{array}{l}\text { Occurs with the passages of the full } \\
\text { moon from the waning moon and } \\
\text { new moon to crescent moon. }\end{array}$ & - \\
\hline Flushing tide & $\begin{array}{l}\text { Occurs with the passage of waning } \\
\text { to new moon and crescent to full } \\
\text { moon. }\end{array}$ & - \\
\hline Dark tide & $\begin{array}{l}\text { Corresponds to the dawn period; } \\
\text { occurs with the new moon. }\end{array}$ & - \\
\hline Twilight tide & $\begin{array}{l}\text { Related to the tide at the beginning } \\
\text { of night time. }\end{array}$ & - \\
\hline High tide or full tide & Maximum level of the high tide. & High tide. \\
\hline Low tide or dried tide & Minimum level of an ebb tide. & Low tide. \\
\hline Thick tide of flood & $\begin{array}{l}\text { The tide rises and its level crosses } \\
\text { half of the beach; it is close almost } \\
\text { to being a high tide. }\end{array}$ & Flood tide \\
\hline Thick tide of ebb & $\begin{array}{l}\text { The tide is decreasing in water } \\
\text { volume after the high tide. }\end{array}$ & Ebb tide. \\
\hline Low tide of flood & $\begin{array}{l}\text { The tide is increasing its level from } \\
\text { the low tide. }\end{array}$ & Flood tide. \\
\hline Low tide of ebb & $\begin{array}{l}\text { The water level is falling; it is close } \\
\text { to the low tide. }\end{array}$ & Ebb tide. \\
\hline Head of dead water & $\begin{array}{l}\text { Presents the end of the neap tide, } \\
\text { when the moon starts to change } \\
\text { phase from full moon to new moon. }\end{array}$ & Slack water \\
\hline
\end{tabular}

longitudinally inside the stern of the canoe; in the bow area, a 'tocheiro' (kerosene lamp) is attached to make the fish jump as a reaction to the light reflection. This fishing strategy usually catches species of the families Belonidae and Mugilidae.

The gillnets can also be set to stay in a vertical position to reach a great part of the water column. This fishing strategy is used in dead tides and in flushing and breaking tides, as the current is slow.
Fishing activities with nets made of silk line, like the mesh net of silk ('tomada') (Fig. 3A) and the drag-net ('arrasto') (Fig. 3B), are also organized according to the tides. The mesh net of silk is employed in the period of the syzygy, flushing and breaking tides, with three stages: (1) the mesh net of silk is set when the tide is low; Laguncunlaria racemosa ('mangue manso') rods are inserted and the net is fixed on the muddy soil; (2) at the peak of the 
high tide, the net is raised and attached to the top end of the rods; (3) in the following low tide, they remove the fish trappped by the net. This network captures species of the families Ariidae, Centropomidae, Gerreidae, Mugilidae and Sciaenidae.

The drag-net is most often used in the breaking and flushing tide, preferably in tidal ranges of lower amplitude, when the sandy-clay-loam banks are exposed with a shallower estuary depth, so the fishermen can drag the net to the shore of the estuary or to the banks. This technique usually catches species in the families Ariidae, Clupeidae, Gerreidae, Sciaenidae, Trichiuridae, Dasyatidae, Gymnuridae, Myliobatidae and Rhynopteridae.

The cast net ('tarrafa') (Fig. 3C) is generally used in the flushing or breaking tide, while the long line (Fig. 3D) with hooks can be used in all types of tides. The castes net catch species such as Mugil curema, Centropomus undecimalis and Pomadasys ramosus, and also other species of the families Ariidae, Clupeidae and Gerreidae, while the long line catches species in the families Ariidae, Dasyatidae, Gymnuridae, Myliobatidae, Rhynopteridae and Serranidae.

Regarding the net technique, it was noticed that the fishing net needle ('agulheira'), gillnets, mullet nets and cast nets are selective because they have meshes compatible with the adult size of the fish they catch, so the ecological impact is lower. The nets with $20 \mathrm{~mm}$ or less are the ones for catching fish in the youth and adulthood stages of various species (e.g. the drag-net and the mesh net of silk). In particular, the fishing net needle must be considered special, because, although its mesh is in the millimeter range, it does not constitute a predatory technique as its size is related to adult 'needle' fish (Belonidae).
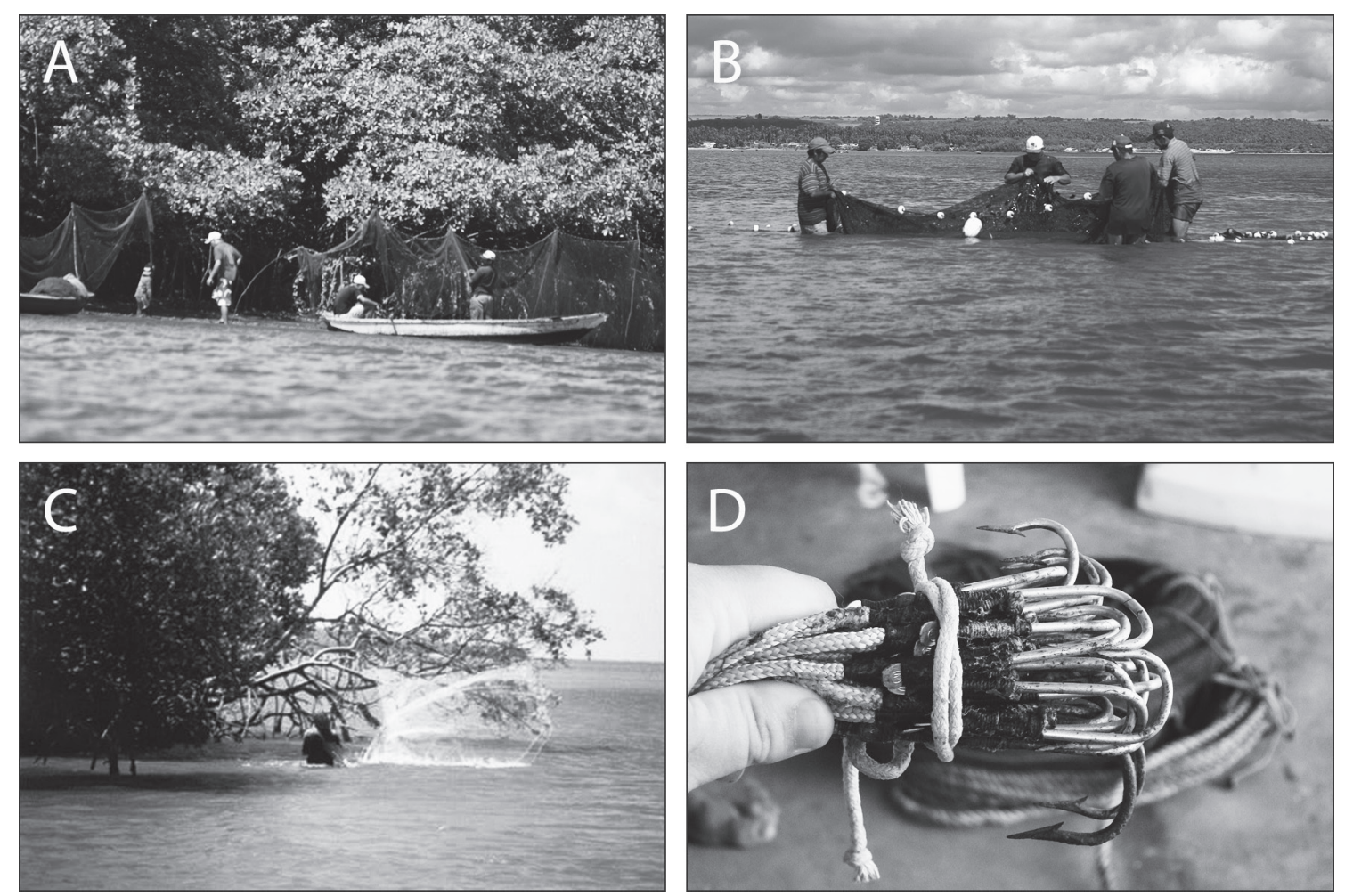

Fig. 3 - A- 'Tomada' net (gillnet) exposed at low tide on the MRE. Photo: José Mourão, 2000; B- fishermen using drag-net on the MRE. Photo: Silvia Soares, 2008; C- fisherman from the community of Barra de Mamanguape using 'tarrafa' (cast net) on the mangrove shore of the MRE. Photo: José Mourão, 2000; D- Hooks of different sizes used by MRE fishermen on the 'espinhel' line. Photo: Patrícia Basílio, 2008. 
However, the nets with a mesh of $25 \mathrm{~mm}$ or more are designed to catch fish in the adult stage, such as the mullet net, the gillnets and the cast net, the latter two having a greater amplitude for catching species due to the way they are used.

TYPES OF WINDS AND THEIR INFLUENCE ON FISHING

TECHNIQUES AND STRATEGIES

The fishermen of the MRE recognize the following types of winds: North, South, East ("vento de fora"), Southeast, Southwest ("terrá"), Northeastern, and Northwestern- whose respective names indicate the direction of their origin. The winds that were cited as the most important were the South, North, East and Southwest. Some fishermen, however, are not familiar with the cardinal directions and have created other names for these winds based on their environmental characteristics. Examples of this situation include "terrá" and "vento de fora" winds, in which the former refers to winds that come from inland areas and blow towards the estuary (corresponding to Southwestern winds) and the latter terminology to winds that blow from the barrier reefs towards the estuary (Eastern winds).

The fishermen consider the North, East, Southwest and Northeastern winds as the best ones for fishing. The East wind was considered the most propitious for fishing by $78.26 \%$ of the fishermen, as it is generally a mild wind that facilitates sailing and tends to collaborate with fish migration from the sea to the estuary. Fully $39.13 \%$ of the fishermen considered the North winds good for fishing because like the East winds, they increase fish movements into the estuary environment. The Southwestern winds were cited by $30.43 \%$ of the fishermen as positive for their fishing activities as these are generally light breezes that facilitate the handling and movement of their boats.

The South wind was considered prejudicial by $39.13 \%$ of the interviewees because it is a strong wind (increasing tidal currents) and tends to conduct the fish towards the open sea. Smaller percentages of fishermen considered Northwestern (4.35\%) and Southeastern $(4.35 \%)$ winds to be unfavorable to fishing activities. Approximately $39 \%$ of the interviewees did not cite any wind direction as unfavorable to their fishing activities, in spite of having cited specific winds that favored their work (Table II).

TABLE II

Percentages of the citations of fishermen (23 interviewees) concerning the types of winds that help or interferein their fishing activities.

\begin{tabular}{lc}
\hline Types of wind & $\begin{array}{c}\text { Porcentage of } \\
\text { citations (\%) }\end{array}$ \\
\hline $\begin{array}{l}\text { Winds that help } \\
\text { in fishing activities }\end{array}$ \\
East & 78.26 \\
North & 39.13 \\
Southwest & 30.43 \\
Northeast & 8.7 \\
South & 8.7 \\
No winds mentioned & 0 \\
& \\
Winds that interfere & \\
in fishing activities & \\
South & \\
Southwest & 39.13 \\
Northeast & 17.39 \\
Northwest & 4.35 \\
Southeast & 4.35 \\
No winds mentioned & 4.35 \\
\hline
\end{tabular}

\section{DISCUSSION}

TIDES ClassifiCATION

Gerhardinger et al. (2009) discuss the role of fishers' Local Ecological Knowledge (LEK) within the management of Marine Protected Areas (MPAs) in Brazil. They mentioned knowledge categories as valuable, including knowledge on tidal cycles, species migrations, sustainable resource exploitation 
rates, site history, birds, navigation, wind behavior and cycles of nature dietary preferences, spawning and mating behaviors, ontogenetic shifts in populations, behavior, location and distribution of fishes, folk habitat classification and folk-taxonomy.

The fishermen of the MRE acknowledge the existence of a relation between the moon phases and variations in tide level. This way of classifying the tidal variation in relation to the lunar phases occurs in a very similar way in various regions of Brazil (Cordell 1974, Alves and Nishida 2002, Ramires and Barrella 2003, Nishida et al. 2006a). Afonso (2006) reports that the Guarani Indians, nowadays located on the Brazilian coast, also know the relation between the lunar phases and the tides, and when they generally go fishing, whether in the river or in the sea, they already know which species of fish will be abundant according to the period of the year and the moon phase. The lunar cycle has been acknowledged by the traditional fishermen as affecting fish behavior (Johannes 1981, Bruyn and Meeuwig 2001). The interpretations described in this research were also similar to the ones presented by Cordell (1974), who researched the fishing communities along the south coast of Bahia, and by Nishida et al. (2006b), who studied mollusks at Paraíba coast. The detailed classification of the lunar cycle of Tokelaun partly indicates that the lunar cycle is important for fishing activities (Ono and Addison 2009). This also corresponds to tidal cycles, which have a strong relationship with fish feeding and other behaviors, and are sometimes one of the factors regulating fishing activities. For Takekawa (2000), the movements of tides is an important factor in fishing, and hunting of dolphins is no exception, as Malaita islanders recognize the phases of the moon that are good for hunting, as well as their corresponding tides.

The tides, according to Garrison (1998), consist of periodic changes of short duration in the height of the ocean surface in a certain place, caused by a combination of the gravitational forces of the moon and sun with and the movement of the Earth. The attraction forces of the moon and sun are added twice in each mooning during the new and full moons, producing spring tides with exceptionally high and low tides, while the sun's attraction forces and those of the moon oppose each other twice in each mooning when it is crescent and half moon, producing high neap tides that are much lower and low tides that are much higher. (Miguens 1995, Thurman 1997) In this situation, it can be observed that the gravitational forces of the sun and moon are added when these celestial bodies are in a confluence position in syzygy, constituting a positive interference; however, in the neap tide situation, they form a destructive interference as the forces tend to annul each other. The high tides thus not so high, and the low tides, not so low (Garrison 1998, Thurman 1997).

According to Miguens (1995), there are also sub-classifications in the scientific classification that encompass: high tide (the highest level reached in an oscillation); low tide (the lowest level reached by the waters in an oscillatiotn); flood tide (the period when the sea level rises); ebb tide (the period when the sea level decreases); and slack water (the period when the sea level stays practically the same).

For Alves and Nishida (2002), the activities of many coastal marine organisms are related to the variation of the tides and, thus, for the traditional communities living in coastal areas where fishing and the extraction of resources from the mangroves form the main family income, knowledge about the moon becomes an important fact for survival with regard to its influence on their gathering and fishing activities, and on the biology of the resources exploited. According to Nordi et al. (2009), on the northeast coast the tide cycle is semi-diurnal, producing two floods and two ebbs per day. So, the MRE fishermen have a detailed understanding about the daily change of the tide levels, which can be noticed their analysis and choice of the right moment to fish. Thus, it was remarked that 
the techniques and strategies of fishing used by the MRE fishermen have a close relation with the moon phases and consequently with the variation of the tides. It may be stated that the moon is the main component acting on the tide cycle, conditioning the rise and fall in sea level, and the speed of flow, which, in turn, influence the presence of fish and in the way they are caught (Cunha 2004).

\section{THE TIDAL INFLUENCES ON FISHING TECHNIQUES}

\section{AND STRATEGIES}

Takekawa (2000), by studying the hunting dolphins in Malaita island, situated at Solomon Islands, says that a particular fishing method is selected according to time, place and target species. The fishing 'zangareia' also takes place at Ponta do Tubarão Reserva de Desenvolvimento Sustentável - RDS [Sustainable Development Reserve] in Rio Grande do Norte State and was described by Dias (2006), although it is also known as 'caiqueira' due to the main aim of the fishing, which is to catch the 'caicos', a small fish like the mullet (Mugilidae), 'sauna' (Mugilidae) and 'carapicu' (Gerreidae), among others. According to Mourão and Nordi (2003), this specific strategy was developed because the fishermen know the 'jumping fish' well, which consists in a behavioral phenomenon related to escape from predators. This nocturnal activity is conducted in the neap tide during the waning gibbous moon, because these nights are dark and the current is lower, thereby enhancing the chance of a good catch. Notwithstanding, some fishermen prefer to work in the new moon phase, because the nights are much darker and this facilitates the catch, especially of mullets (Mugil sp.) and 'needle' fishes (Belonidae). At Ponta do Tubarão Sustainable Development Reserve, this technique is known as lamp fishing (Dias 2006).

So, a certain tide can clearly impede the efficiency of one technique and boost the efficiency of another, or completely obstruct the use of a third. According to Mourão (2000), the movements of tides related to the lunar phases are the chief elements that determine the fishing strategies. Costa-Neto and Marques (2000, 2001), who studied traditional fishing communities in Conde, Bahia State, also concluded that knowledge on the lunar calendar results in adaptation, using the appropriate technique applied at the right moment for a particular species. Ono and Addison (2009) mentioned that the lunar cycle is strongly related to fishing activities in Tokelau, New Zealand. The knowledge on the relationship between each fish species' behavior and lunar and seasonal cycles have been passed down by Tokelauan males through several generations.

The variety of fishing techniques, there existing more generalist and more selective techniques, is related to the diversity of fish species found in the mangrove-estuary complex. The selective ones are characterized by catching the species in the adulthood phase and/or of a size established by law (e.g., the method for catching mullets Mugil sp.). On the other hand, the generalist techniques, such as use of the mesh net of silk, are considered to have more impact on the ecosystem as they catch species of various sizes and development phases.

The drag-net and the mesh net of silk are characterized by a very reduced mesh size $(10 \mathrm{~mm}$ to $20 \mathrm{~mm}$ ), the young and the adult being caught, not by getting stuck in the net, but by being retained in it. So, such nets can be considered as predatory from the ecological point of view. Nevertheless, there is no Brazilian Environmental Protection Agency (IBAMA) resolution or State law to regulate the minimum mesh sizes.

TYPES OF WINDS AND THEIR INFLUENCE ON FISHING TECHNIQUES AND STRATEGIES

Wind is an essential abiotic factor of great importance in fishing. The influence of wind on fishing activity was well covered by Lima and Pereira (1997) who studied fishermen from Itaipu. They presented their classification as 'the best', 'better', 'worse' and 
'the worst' winds, and explained how they named them. Furthermore, a correlation was made between the wind and the season (summer or winter), was not comprised by this study. Takekawa (2000) also showed the influence of winds in hunting dolphins. According to this author, from May to December the trade winds blow constantly from the Southeast, creating rough seas that prevent the hunting of dolphins because they can damage small canoes, while from January to April, the Northwest, West and East winds are considered the best for hunting dolphins, according to the residents of Malaita island.

In Allut (2000), the classification of the winds made by the fishermen from La Coruña (Spanish province) shows groups of winds according to their origin of direction: 'winds from outside' (SW, W and NW), winds from the land (E and SE), north winds (NE and N) and the 'winds from below' or storm weather (S). It appears that the qualification of these winds is related to the presence of fish in the estuary. According to Miguens (1995), the transport of water induced by the wind performs an important role in the circulation of the ocean surface. In certain regions, winds cause vertical water movements, which bring to the surface substances that favor the abundant development of phyloplankton, thus promoting the fertilization of the region and attracting shoals.

It can be noticed that the faults and qualities attributed to the winds by the MRE fishermen, are in accordance with the way they aid or hinder the fishery. Allut (2000) states that the La Coruña fishermen also personify the natural phenomena; they refer to the winds as brave, good, bad, false and loveable.

\section{CONCLUSION}

Tides and winds constitute environmental factors that are significant enough for determining fishing strategies and techniques to be used by the MRE fishermen. The accumulated knowledge of the local fishing communities has extreme validity regarding the abiotic factors related to the distribution of fishing resources. It was observed that local knowledge about the tides was more detailed, probably because the tides greatly influence their fishing activities, as well as about a wide range of ecological processes related to the presence of fish in that estuarine environment.

\section{ACKNOWLEDGMENTS}

Thanks to all communities in Barra de Mamaguape and Tramataia whoprovided information collaborated with the development of this work; and to those for the kind hospitality; to Conselho Nacional de Desenvolvimento Científico e Tecnológico (CNPq) for the financial support and for the scholarship of the Institutional Scholarship Program for Scientific Initiation; and to the APA of Mamanguape River Estuary for their logistical support.

\section{RESUMO}

Este trabalho foi desenvolvido junto a duas comunidades de pescadores artesanais: Barra de Mamanguape e Tramataia, Nordeste do Brasil. O objetivo foi estudar o conhecimento e a percepção dos pescadores artesanais sobre a classificação das marés e dos ventos bem como as técnicas e estratégias de pesca. A metodologia empregada envolveu várias técnicas: entrevistas livres, entrevistas semiestruturadas, turnês guiadas e observação direta. Os resultados obtidos junto aos pescadores mostraram a classificação das marés de acordo com as fases lunares em: 'maré de quebramento', 'maré de lançamento', 'maré morta' e 'maré grande', designadas tecnicamente estas últimas como maré de quadratura e maré de sizígia, respectivamente. $\mathrm{O}$ vento é também um fator essencial no sucesso da pescaria, eles o classificam de acordo com a direção: Norte, Sul, Leste, Sudeste, Sudoeste, Nordeste, Noroeste. Os dados obtidos nesta pesquisa mostraram que o conhecimento dos pescadores pode ser útil na elaboração de planos de manejo e nos estudos de conservação para este estuário.

Palavras-chave: Pesca artesanal, etnoictiologia, peixes, comunidades pesqueiras, ciclo lua-maré. 


\section{REFERENCES}

AFONSO G. 2006. Estações no céu tupi-guarani. Sci Am. Brasil: edição especial (Etnoastronomia) 14: 46-55.

Allut AG. 2000. O conhecimento dos especialistas e seu papel no desenho de novas políticas pesqueiras. In: DIEGUES AC (Org), Etnoconservação: novos rumos para a conservação da Natureza. São Paulo: Hucitec NUPAUB - USP, p.101-123.

ALVES RRN AND NISHIDA AK. 2002. A ecdise do caranguejouçá, Ucides cordatus L. (Decapoda, Brachyura) na visão dos caranguejeiros. Interciencia 27: 1-8.

ANWANI S AND VACCARO I. 2008. Lagoon ecology and social strategies: habitat diversity and ethnobiology. Hum Ecol 36: 325-341.

BAILEY KD. 1982. Methods of social research. McMillan Publishers: The Free Press, New York, 408 p.

BERKES F. 1999. Sacred ecology: traditional ecological knowledgeand resource management. Taylor and Francis, Philadelphia, $209 \mathrm{p}$.

BRUYN AMH AND MeEuWIG JJ. 2001. Detecting lunar cycles in marine ecology: periodic regression versus categorical ANOVA. Mar Ecol Prog Ser 214: 307-310.

CARDoso ES. 2001. Pescadores artesanais: natureza, território, movimento social. 143 f. Tese (Doutorado). USP, São Paulo, SP.

Chaves PT AND Robert MC. 2003. Embarcações, artes e procedimentos da pesca artesanal no litoral sul do estado do Paraná, Brasil. Atlântica 25: 53-59.

CORDELl J. 1974. The lunar-tide fishing cycle in northeastern Brazil. Ethnology 13: 379-392.

Costa-Neto EM and Marques JGW. 2000. Conhecimento Ictiológico Tradicional e a Distribuição temporal e espacial de recursos pesqueiros pelos pescadores de Conde, Estado da Bahia, Brasil. Etnoecol 4: 56-67.

Costa-Neto EM AND Marques JGW. 2001. Atividades de pesca desenvolvidas por pescadores da comunidade de Siribinha, município de Conde, Bahia: uma abordagem etnoecológica. Sitientibus 1: 71-78.

Cunha LHO. 2004. Saberes patrimoniais pesqueiros. In: DIEGUES AC (Org), Enciclopédia caiçara. São Paulo: Hucitec: NUPAUB: CEC/ESP, p. 105-114.

DIAS TLP. 2006. Os peixes, a pesca e os pescadores da Reserva de Desenvolvimento Sustentável Ponta do Tubarão (Macau-Guamaré/RN), Brasil. 162 f. Tese (Doutorado em Ciências Biológicas), Universidade Federal da Paraíba, João Pessoa, PB.

DREW JA. 2005. Use of traditional ecological knowledge in marine conservation. Conserv Biol 19: 1286-1293.

GARRISON T. 1998. Oceonagraphy: an invitation to marine science. Belmont: Wadsworth, $567 \mathrm{p}$.

GERHARDINGER LC, GODOY EAS AND JONES PJS. 2009. Local ecological knowledge and the management of marine protected areas in Brazil. Ocean Coast Manage 52: 154-165.

GODEFROID RS, SPACH HL, SCHWARZ JR R, QUEIROZ GMN AND OLIVEIRA Neto JF. 2003. Efeito da lua e da maré na captura de peixes em uma planície de maré da baía de Paranaguá, Paraná, Brasil. B Tec Inst Pesca 29: 47-55.
JOHANNES RE. 1978. Reproductive strategies of coastal marine fishes in the tropics. Environ Biol Fishes 3: 65-84.

JOHANNES RE. 1981. Working with fishermen to improve coastal tropical fisheries and resource management. Bull Mar Sci 31: 673-680.

KUPARINEN A, O'HARARB AND MERIL J. 2009. Lunar periodicity and the timing of river entry in Atlantic salmon Salmo salar. J Fish Biol 74: 2401-2408.

LIMA RK AND PEREIRA LF. 1997. Pescadores de Itaipu: meio ambiente, conflito e ritual no litoral do Estado do Rio de Janeiro. Niterói: EDUFF, 333 p.

MAIA ICC AND RochA-BARREIRA CA. 2008. Caracterização da atividade de captura de organismos da zona entremarés, em recifes de arenito do litoral do Ceará, Brasil. Arq Cien Mar 41: 67-73.

Miguens AP. 1995. Marés e correntes de maré; correntes oceânicas. In: Navegação: a ciência e a arte. Volume I - Navegação costeira, estimada e em águas restritas. Niterói: Diretoria de Hidrografia e Navegação da Marinha do Brasil, p. 227-274.

Montenegro SCS, Nordi N And Marques JGW. 2001. Contexto cultural, ecológico e econômico da produção e ocupação dos espaços de pesca pelos pescadores de pitu (Macrobrachium carcinus) em um trecho do Baixo São Francisco, Alagoas, Brasil. Interciencia 26: 535-540.

MOURÃO JS. 2000. Classificação e Ecologia de peixes estuarinos por pescadores do estuário do rio Mamanguape. $132 \mathrm{f}$ Tese (Doutorado). UFSCar, São Carlos, SP.

MOURÃO JS AND NORDI N. 2003. Etnoictiologia de pescadores artesanais do Estuário do Rio Mamanguape, Paraíba, Brasil. B Tec. Inst Pesca 29: 9-17.

NetTo RF, NunEs AGA AND AlBINO J. 2002. A pesca realizada na comunidade de pescadores artesanais de Santa CruzES - Brasil. B Tec Inst Pesca 28: 93-100.

NISHIDAAK. 2000. Catadores de moluscos do litoral paraibano: estratégias de subsistência e formas de percepção da natureza. 144 f. Tese (Doutorado) UFSCar, PPGERN, São Carlos, SP.

NishidA AK, NIVALdo N AND ALVES RRN. 2006a. The lunartide cycle viewed by crustacean and mollusc gatherers in the State of Paraíba, Northeast Brazil and their influence on collection attitudes. J Ethnobiol Ethnomed 2: 1-12.

Nishida AK, Nivaldo N AND Alves RRN. 2006b. Molluscs production associated to lunar-tide cycle: a case study in Paraíba State under ethnoecology viewpoint. J Ethnobiol Ethnomed 2: 1-6.

Nordi N, NishidA AK AND ALves RRN. 2009. Effectiveness of Two Gathering Techniques for Ucides cordatus in Northeast Brazil: Implications for the Sustainability of Mangrove Ecosystems. Hum Ecol 37: 121-127.

ONO R AND ADDISON DJ. 2009. Ethnoecology and Tokelauan fishing lore from Atafu Atoll, Tokelau. SPC Traditional Marine Resource Management and Knowledge Information Bulletin 26: 3-22. 
PAludo D AND KlonowsKi V. 1999. Barra de Mamanguape - PB: estudo do impacto do uso de madeira de manguezal pela população extrativista e da possibilidade de reflorestamento e manejo dos recursos madeireiros. São Paulo: MAB - UNESCO - MMA, Série Cadernos da Reserva da Biosfera da Mata Atlântica 16: 7-54.

QUINNNJAND KOJIS BL. 1981. The lack of changes in nocturnal estuarine fish assemblages between new and full moon phases in Serpentine Creek, Queensland. Environ Biol Fishes 6: 213-218.

RAMires M AND BARRELla W. 2003. Ecologia da pesca artesanal em populações caiçaras da Estação Ecológica de Juréia-Itatins, São Paulo, Brasil. Interciencia 28: 208-213.

RoOKER JR AND DENNIS GD. 1991. Diel, lunar and seasonal changes in a mangrove fish assemblage off Southwestern Puerto Rico. Bull Mar Sci 49: 684-698.
SANCHES RA. 2001. Caiçara Communities of the Southeastern Coast of São Paulo State (Brazil): Traditional Activities and Conservation Policy for the Atlantic Rain Forest. Soc Hum Ecol 8: 52-64.

SILVANO RAM. 2004. Pesca artesanal e etnoictiologia. In: BEGOSSI A (Org), Ecologia de pescadores da Mata Atlântica e da Amazônia. São Paulo: Hucitec, Nepam/ Unicamp: Nupaub/USP Fapesp, p. 187-222.

STEBBINS RA. 1987. Fitting in: the researcher as learner and participant. Qual Quant 21: 103-108.

TAKEKAWA D. 2000. Hunting method and the ecological knowledge of dolphins among the Fanalei villagers of Malaita, Solomon Islands. SPC Traditional Marine Resource Management and Knowledge Information Bulletin 12: 3-11.

THURMAN HV. 1997. Introductory Oceanography. New Jersey: Prentice-Hall, 544 p. 